Article

\title{
Applying User-Perceived Value to Determine Motivators of Electricity Use in a Solar Photovoltaic Implementation in a Philippine Island
}

\author{
Lorafe Lozano $1,2, *$ (D) and Evelyn Taboada ${ }^{1,3}$ \\ 1 Center for Research in Energy Systems and Technologies (CREST) and Engineering Graduate Program, \\ School of Engineering, University of San Carlos, Cebu City 6000, Philippines; ebtaboada@usc.edu.ph \\ 2 Department of Industrial Engineering, University of San Carlos, Cebu City 6000, Philippines \\ 3 Department of Chemical Engineering, University of San Carlos, Cebu City 6000, Philippines \\ * Correspondence: Iflozano@usc.edu.ph; Tel.: +63-998-790-7585
}

check for updates

Citation: Lozano, L.; Taboada, E. Applying User-Perceived Value to Determine Motivators of Electricity Use in a Solar Photovoltaic Implementation in a Philippine Island. Sustainability 2021, 13, 8043. https://doi.org/10.3390/su13148043

Academic Editors: Luca Cioccolanti, Electo Eduardo Silva Lora and Mauro Villarini

Received: 3 April 2021

Accepted: 15 July 2021

Published: 19 July 2021

Publisher's Note: MDPI stays neutral with regard to jurisdictional claims in published maps and institutional affiliations.

Copyright: (c) 2021 by the authors. Licensee MDPI, Basel, Switzerland. This article is an open access article distributed under the terms and conditions of the Creative Commons Attribution (CC BY) license (https:// creativecommons.org/licenses/by/ $4.0 /)$.

\begin{abstract}
The most practical solution for over 70\% of the world's unelectrified population is decentralized electrification, usually with renewable energy integration. The sustainability of these systems has been a central issue with studies looking at its multidimensional nature. However, perhaps the most overlooked aspect is the ability of the consumers to proactively use electricity. This paper addresses this urgent need to understand not just the sustainability from exogenous factors but, more importantly, from the factors that motivate the end-users to consume electricity. Applying the concept of user-perceived value (UPV) in electrification, a proposed multidimensional assessment framework, consisting of 12 motivators, was grouped according to UPV categories. Using a 5-point Likert scale questionnaire, 29 beneficiaries in Gilutongan Island, Cordova, Cebu, Philippines, were asked to evaluate their motivation to consume electricity, six months after they were provided with increased electricity access through a $7.92 \mathrm{kWp}$ solar photovoltaic installation. Analysis showed that the households regarded 9 of the 12 factors as moderate to strong motivators, with better social standing compared to other households without electricity and the ability to engage in productive uses of electricity emerging as the strongest influencers. The proposed framework is deemed beneficial to policy-makers to pragmatically understand what drives rural households to proactively consume electricity and implement developments and policies to stimulate an increase in demand.
\end{abstract}

Keywords: rural electrification; isolated islands; user-perceived value; electricity consumption drivers; renewable energy

\section{Introduction}

One of the United Nations' sustainable development goals (SDG) is SDG7-to ensure universal access to affordable, reliable, sustainable, and modern energy. Over the years, global organizations have endeavored to provide universal access, especially to marginalized populations around the world. Their efforts have paid off as the number of unelectrified population has been reduced from 1.2 billion in 2010 to 840 million in 2017 [1]. According to the 2020 progress report on SDG7, global electrification rate has improved from $83 \%$ in 2010 to $90 \%$ in 2018 with steady growth of the renewable energy share in the electricity supply from $16.3 \%$ in 2010 to $17.3 \%$ in 2017 [2]. The majority of the unelectrified population live in sub-Saharan Africa and in the least-developed countries in Asia. In most cases, these regions are isolated and off-grid such that cost-effective electrification relies on decentralized energy systems (DES) integrated with renewable energy technology (RET) $[3,4]$.

There is some uncertainty as to the sustainability of DES, and studies have already been undertaken to determine these challenges within several identified dimensions and indicators. Ineffective prioritization, biased decision-making process, and information 
gaps that limit appropriate planning mechanisms affect the long-term sustainability of DES projects in rural areas [5,6]. From a technical standpoint, one of the palpable issues with DES, especially with RET deployments, is the intermittent nature of renewable energy sources that necessitates the integration of battery energy storage systems (BESS), thereby increasing capital requirements [7-9]. While diesel generator sets might address the issue on high capitalization of renewable energy technologies, running electricity on conventional fossil fuels will prove to be more costly in the long term [10]. Another salient point is the possibility of over- or underestimating system capacity due to the indeterminate electricity demand in rural areas, which could also impact the effective management of capital costs [11-13]. Typical business models also hand over operations and maintenance of DES to the local community, and the lack of competence and capabilities of these local organizations tend to result in system failures [14]. The need to empower end-users to enable pro-active participation through capacity building becomes an obligatory step towards sustainable implementation [15].

The high capitalization requirements of DES compel national governments to entrust rural electrification efforts to private parties, small developers, and even the local communities [16]. However, because of the uncertain energy markets in off-grid areas, there can be some reluctance from private investors to scale up electricity access. The success of such projects is considered to largely depend on the level of government commitment and the robustness of institutional frameworks and enabling policies to support these stakeholders, especially through financial incentivization $[17,18]$. The strength of institutional frameworks and not the technology is deemed as a more influential determinant of rural electrification sustainability [19]. Governments must address the disorganization within policies and within regulatory bodies with respect to rural electrification to enable a more streamlined strategy towards addressing energy access in isolated areas and, likewise, must strengthen research and development to address information gaps and must enforce adequate capacity building and knowledge transfer amongst adopters to reduce or eliminate energy mismanagement [20].

While deliberating on the multidimensionality of rural electrification could help in the sustainable implementation of energy access projects, the most logical preliminary issue to address is the ability of electrification systems to meet the end-users' actual needs [21]. The adoption of DES, especially those that integrate renewable energy technologies, in providing increased electricity access to rural areas is seen to promote socio-economic development of the community and the consumers. However, the perceived high investment requirements underrate the future benefits of renewable energy deployments, forcing rural consumers, whose typical livelihoods do not require electricity, to turn down such developments [22]. There is also an argument that while rural electrification does provide for socio-economic development of the community, the benefits are mostly biased towards users with higher average expenditures and incomes [23]. Thus, for DES in rural areas to be sustained, there is an urgent need to determine not just the long-term economic and environmental impacts of adopting renewable energy but, more importantly, how these projects can affect individual social and economic benefits to the end-users [24].

Several studies have been made to evaluate sustainable rural electrification from a multidimensional perspective, and the economic, technical, social, environmental, and institutional dimensions have been extensively applied in literature to ascertain the impacts of rural electrification projects to the community as well as its sustainability [25-29]. These studies, however, tend to focus on the exogeny of these multidimensional factors and consider how these external factors affect sustainable implementation and deployment of electrification projects. There is an emergent lack of consideration for the endogenous elements of sustainability, particularly concerning how individual consumers perceive the value of electrification to their existence and how they are motivated to consume electricity. The study of Hirmer and Guthrie (2016) has proposed a user-perceived value framework in understanding how technological innovations in electrification can be fitted to the needs of rural consumers in order to increase user acceptance [30]. 
This research was built around the propositions in this study and intended to determine what drives households in rural communities to consume electricity considering the user-perceived value perspective and taking into account the economic and non-economic drivers of electricity consumption in rural areas. The study followed a multidimensional assessment (MDA) framework where the goal was to determine the drivers that encouraged the proactive consumption of electricity in rural community households. The research was applied in Gilutongan Island, where a $7.92 \mathrm{kWp}$ solar photovoltaic (PV) system was installed to provide increased electricity access to selected household beneficiaries. The evaluation considered what motivates households to consume electricity and was done at household level. Scoring of the drivers to electricity consumption was done to better understand what motivates rural households to consume electricity once they have been given increased access. Moreover, further analysis was done to determine if motivation was influenced by educational attainment of the respondents and monthly income of the households. Section 2 of this paper presents a review of the drivers of electricity consumption in rural areas, while the methods are discussed in Section 3. Section 4 presents the discussion and analysis of the evaluation. Section 5 discusses the potential impacts of the framework to rural electrification initiatives in the Philippines, while Section 6 presents the conclusions and policy implications.

\section{Understanding the Drivers of Electricity Consumption in Rural Areas}

With the intensifying global electrification efforts, there is now widespread electricity access in rural populations across the world. Additionally, while work towards extending access to the millions who are still without electricity is in progress, there exists a current and urgent challenge to the success of rural electrification developments. The question of sustainable consumption of end-users has become a forefront issue, and understanding why rural households are cautious to consume electricity and how to stimulate them to increase their demand has become a critical challenge to sustainable rural electrification [31]. Moreover, the sustainable adoption of renewable energy technologies in the rural setting highly depends on the acceptance and the proactive electricity consumption of the rural communities where these technologies are deployed [32]. These points highlight the necessity to understand what motivates rural communities to consume electricity.

Hirmer and Guthrie (2016) proposed a user-perceived value (UPV) perspective in understanding the consumption patterns and behaviors of rural communities [30], where UPV was defined as the extent to which a good or service meets the consumer's needs and wants. It was postulated that in understanding this, project developers are able to better understand consumer decisions, which until now, have not been extensively considered in the implementation of rural development programs. The value perceived by end-users of rural electrification projects poses a significant role in the success and sustainability of these initiatives that goes beyond the common elements of financial value, technology choices, and capacity building, as it influences the uptake and acceptance of such projects [33]. Despite the obvious socio-economic benefits of increasing electricity access, the successful adoption, as with any other technology or innovation, relies on how effectively it can be sold to the end consumers [34], and thus, relies on how consumers perceive the value of electricity access to their entity and existence. In a case study in rural India, consumers were seen to value availability of electricity power, reliability, and price, with consumers inclined to pay more provided that the supply was reliable, as opposed to low-cost but erratic supply [35]. End-users, while predisposed to value the benefits of electrification to health, work, and education, also regarded the autonomy of children, improvement in family life, and reduction of stress as driving aspects to adoption and acceptance of technology [36].

There is also a tendency for project developers to focus on designing a reliable and affordable electricity generation system, neglecting the demand aspect, the values placed by the end-users on the energy service, and the consumers' preferences in terms of electricity consumption [37]. The need for social acceptance of renewable energy technologies has 
been highlighted in numerous sustainability studies for energy access as this also impacts how communities are motivated to consume electricity [38-40]. Concerns about cost and inequality, as well as potential abusive and inequitable business practices, are significant points that could lead to unacceptability of electrification technologies in rural areas [40]. Moreover, slow diffusion of electrification technologies in the rural communities can be attributed to the end-consumers' lack of information and ability to test the technologies, such that prior deployments and the visibility of successful implementations with neighboring communities is a more useful approach of communicating consumer benefits rather than simple word-of-mouth [41]. Information, coupled with active social involvement, is also cited as a fundamental ingredient in the successful promotion of ocean wave energy as a renewable energy resource [42]. The effective engagement of the local community and the improvement of consumer behaviors, particularly in using efficient electrical appliances, are key factors in the sustainability of minigrid deployments [43].

The motivation of households to consume energy is also deemed to be influenced by several demographic factors. In a case study in Iran, household income was seen to potentially lead to variation in electricity consumption, whereas head-of-household age did not have any significant impact [44]. Aside from income, factors such as gender, age, household size, and having children in the household were also seen to influence the level of electricity consumption patterns among households $[45,46]$. In a study in Greece, a positive correlation was seen between energy consumption and income, age, employed members in the household, and gender [47]. Moreover, the study concluded that households with higher educational levels tend to use electrical appliances more intensively than households with lower educational levels.

Consumers play a crucial role in the successful adoption and sustainable deployment of electrification systems and renewable energy technology, especially in rural areas where people's livelihoods are not dependent on electricity. Simply providing for electricity access to rural communities does not imply growth and development, as the need for the communities to proactively consume electricity, especially through productive means, is critical to sustainable development [48]. While economic impacts to the community and the mitigation of climate change are good indicators of the sustainability of electrification, there is a more exigent need to look at the social implications of electrification and determine how consumers are motivated to use the technology and how acceptable the technologies are at end-user levels $[49,50]$. Therefore, the need to identify what drives end-users to consume electricity and the perceived value they associate to increased access is crucial, especially in rural electrification initiatives (refer to Table 1).

Table 1. Drivers of electricity consumption in rural areas in published literature.

\begin{tabular}{|c|c|c|}
\hline Driver & Sub-Driver & References \\
\hline Economy & $\begin{array}{l}\text { Affordability of electricity tariff, productive use of electricity (community-level) or } \\
\text { local entrepreneurship }\end{array}$ & {$[48,51-55]$} \\
\hline Technology & $\begin{array}{c}\text { Reliability of system, eser interface (metering), appropriateness, adequacy of } \\
\text { supply, ease of repair }\end{array}$ & {$[48,51]$} \\
\hline Household energy use & $\begin{array}{l}\text { Access to information/entertainment/other conveniences, knowledge attainment, } \\
\text { business opportunities, togetherness, operational expenditure, local demand }\end{array}$ & {$[52,53,55]$} \\
\hline Community services & Security/comfort/safety, health and wellbeing, business opportunities & [52-55] \\
\hline Organization & $\begin{array}{c}\text { Maintenance (ability to operate without need for specialized staff), ownership, } \\
\text { grassroots organising }\end{array}$ & {$[51,55]$} \\
\hline Poverty mitigation & Pro-poor policies & [55] \\
\hline
\end{tabular}




\section{Materials and Methods}

\subsection{Conceptual Framework}

User-perceived value is a significant determinant of the attitude of users to a certain product or service and the impact of user behavior to product or service satisfaction, thus, establishing its user-perceived effectiveness [56]. In most cases, user-perceived value is established considering user satisfaction and multidimensional variables that achieve such satisfaction. Typical dimensions considered are the functional value, emotional value, social value, conditional value, and epistemic value $[57,58]$, while other dimensions are service performance value, monetary value, brand integration value, and convenience value [59]. These context-related (conditional, epistemic) and content-related (emotional, social, convenience, monetary) values are perceived to lead to loyalty (commitment, purchase intentions) and, thus, can lead to outcomes (willingness to pay) [60]. In some cases, the customer-perceived value is deemed to be correlated to the perceived benefits and perceived sacrifices experienced by the consumers [61-63].

In the context of rural electrification, it is deemed worthwhile to consider how users regard the benefits of increasing rural electricity access, as policies have shifted to private capitalization and rural electrification projects have become commercial ventures. Sustainability of such projects rely on consumers' socio-economic growth that improves their capacity to pay, as well as their proactive consumption of electricity, as energy access projects that are heavily dependent on donations seldom see sustainable results [64-66]. However, the concept of user-perceived value is not extensively applied in research related to rural electrification projects with research emphasizing the economic, technical, or environmental barriers to project realization and sustainability and downplaying consumer value perception and user behavior $[67,68]$. Studies that do consider user value proposition consider that technologies influence complex processes that push for the sustainability of technological innovations [69-71].

This research is grounded on the user-perceived value concept as discussed in Hirmer and Guthrie (2016) [30] and follows the established pillars used to determine user-perceived value as discussed in Hirmer (2014) [33] in determining what motivates rural households to consume electricity. It is understood that most rural electrification initiatives rely on raising awareness and educating the consumers of the social, economic, and environmental impacts of electrification rather than convincing users that developed initiatives to meet their needs are something that they ought to want. The typical pillars to determine user-perceived value, as discussed by Hirmer (2014), are the: (1) functional value-which corresponds to economy, quality and performance, convenience, physical compatibility, and service); (2) social significance value - which corresponds to identity and status; (3) epistemic value - which corresponds to novelty, knowledge, and curiosity; (4) emotional value-which corresponds to association, fun, memorability, and safety; and (5) cultural value-which corresponds to tradition, religion, and spirituality. Figure 1 presents the framework in assessing what motivates households in rural communities to consume electricity, following the concepts from Hirmer and Guthrie (2016), Hirmer (2014), and the drivers identified in Table 1. The framework makes use of user-perceived values in determining what motivates rural consumers to consume electricity. It contends that functional, social, epistemic, emotional, and economic values establish the overall user-perceived value of increased electrification, which in turn, drives rural households to consume electricity. This motivation to consume ultimately leads to consumer satisfaction of and loyalty to the increased electrification service. 


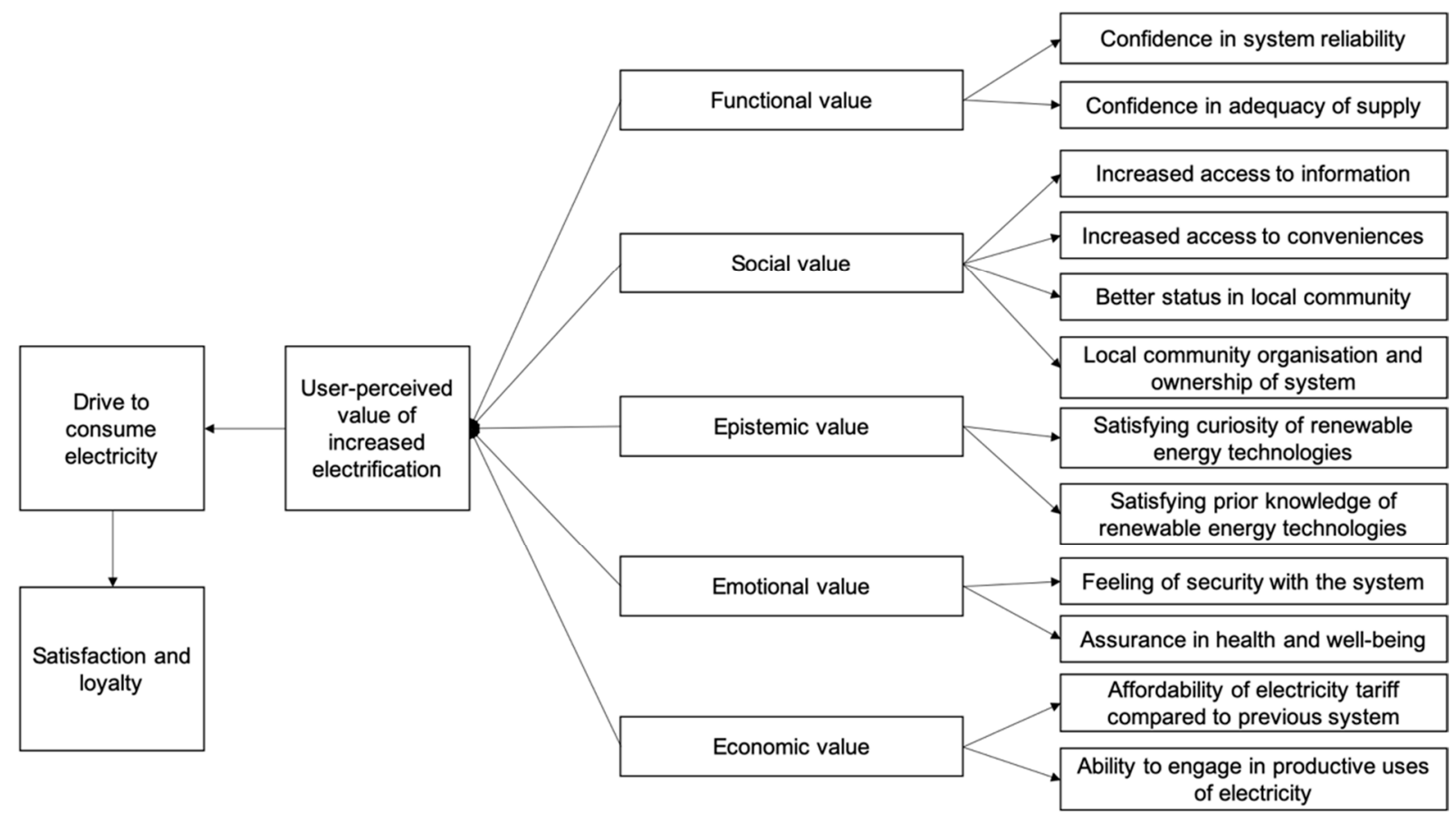

Figure 1. Proposed multidimensional assessment framework for household electricity consumption drivers in rural communities.

\subsection{Case Environment}

Gilutongan Island $\left(10^{\circ} 12^{\prime} 00^{\prime \prime} \mathrm{N}, 123^{\circ} 59^{\prime} 00^{\prime \prime} \mathrm{E}\right)$ is an island village (barangay) under the jurisdiction of Cordova, Cebu. The island is currently powered by a $194 \mathrm{kVA}$ diesel generator set that provides electricity to the island residents for $4.5 \mathrm{~h}$ every night. Residents who are connected to the generator pay US\$ 0.14 (Php 7) per light bulb and US\$ 0.15 (Php 8) per power outlet every day. The payment is collected daily by designated representatives of the local government unit (LGU) and payment collections are used to purchase diesel to power up the generator. As of the 2019 report of the island's local government unit, there are a total of 2179 people and 370 households on the island. The barangay is composed of four sub-villages (sitios). There is an integrated school on the island that serves elementary to senior high school students, a health care center, churches of different religions, a private restaurant for tourists, and a private resort that is not yet operational.

In March 2020, a $7.92 \mathrm{kWp}$ solar photovoltaic system with $28.8 \mathrm{kWh}$ battery energy storage system was installed in one of the sub-villages (sitios) on the island to provide increased electricity access to 11 household beneficiaries composed of 44 individuals. The system was installed on two rooftops located within the vicinity of the 11 household beneficiaries (see Figure 2). Initially, the households used telephone wires and undersized wires to connect to the main distribution line of the diesel generation system and did not use electrical safety devices, such as switches and circuit breakers, such that lights and appliances were immediately turned on when the diesel generator was turned on. With the provision of the solar PV system, the distribution system of the beneficiary households was also improved with distribution wires, switches, and breakers, installed according to Philippine electrical standards. For one year after the installation, the households were provided with 24-h electricity, except for 17 days when service disruptions were recorded due to battery depletion caused by insufficient solar charging. Each household was provided with an electric meter for easy tracking of their daily consumption. The household beneficiaries paid a flat rate of US $\$ 0.4$ per day provided that their consumption did not exceed $1 \mathrm{kWh}$ per day. Households who consumed more than $1 \mathrm{kWh}$ per day paid a tariff computed based on the rate of US\$ 0.4 per $\mathrm{kWh}$. 


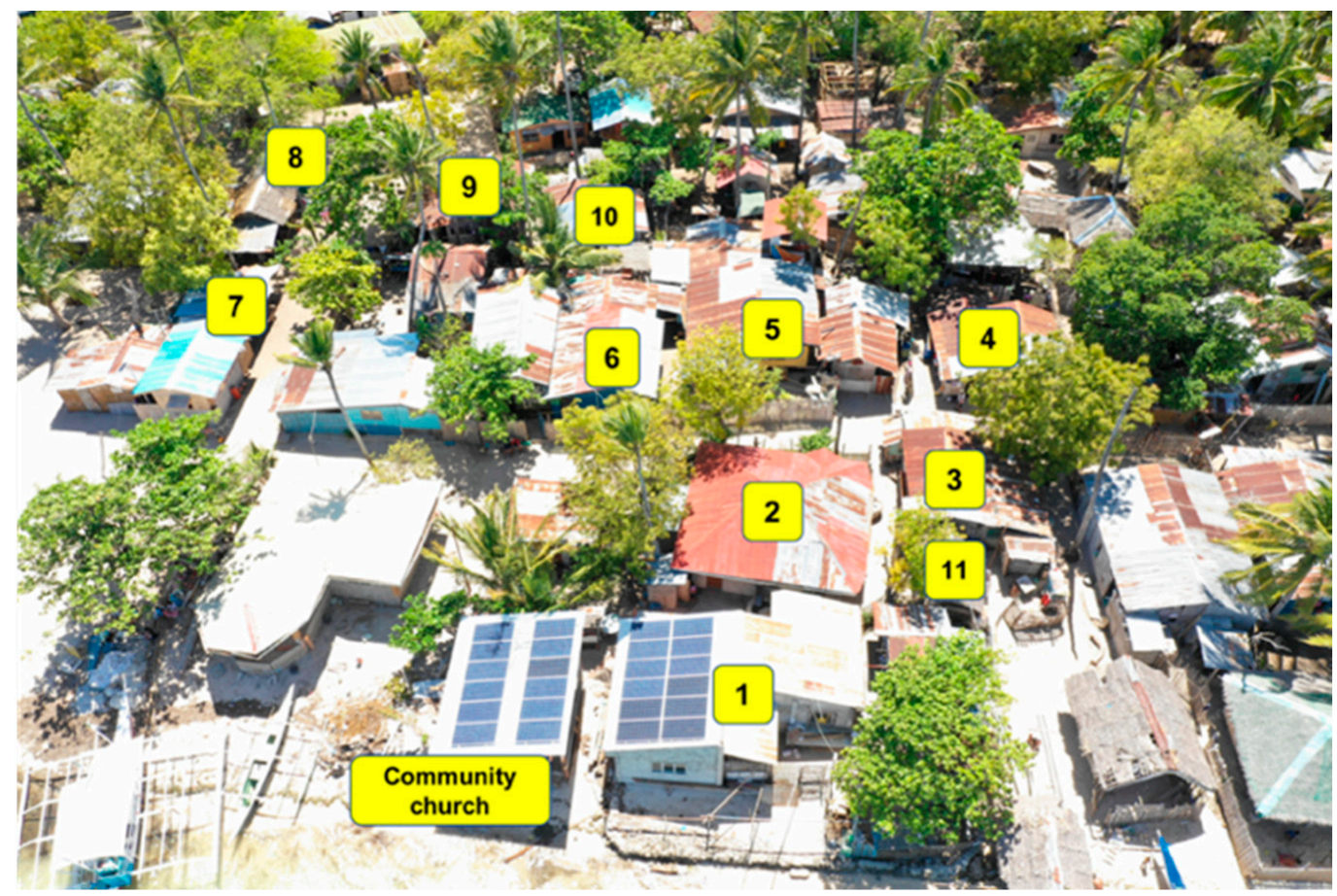

Figure 2. Location of household beneficiaries in Gilutongan Island, Cebu, Philippines. (Note: numbered roofs are the houses of the beneficiaries).

\subsection{Data Collection and Treatment}

Data were collected from beneficiaries who were of legal age and were already contributing to the household income. This meant that of the 44 individual beneficiaries, 29 were the respondents. A survey instrument was developed to determine consumption motivators of the respondents and reviewed by the Ethics Review Committee of the researchers' academic institution. The survey was divided into three parts: the first part explored the demographic information of the household beneficiaries; the second part sought to determine their current status after increased electricity access had been provided; and the third part aimed to establish how certain factors motivated or deterred households from consuming electricity. The third part contained statements about what motivated rural households to consume electricity and was designed based on a 5-point Likert scale with degrees defined as strongly agree, agree, neutral, disagree, and strongly disagree to the statements (see Appendix A: Table A1). The data were collected through guided individual interviews of the respondents so that no respondent was influenced by the answers of the other respondents. The questionnaire was translated in the local dialect and the respondents' answers were subsequently transcribed and translated to the English language.

Descriptive analysis was used to interpret collected data, where modes were calculated to determine the degree of influence of a motivator over the drive of the rural population to consume electricity; although means and median were likewise established. The mode was considered the more appropriate measure, providing the value at which the probability mass function took its maximum value, while the mean hardly provide an appropriate measure of motivations, as the degree of motivation could not be inferred by a non-integer value [72]. In the analysis, numerical values were assigned to the respondents' answers to each motivator statement, assigned as follows: strongly agree -5 ; agree -4 ; neutral -3 ; disagree-2; and strongly disagree- 1 .

Regression analysis was done to establish the relationship between the motivators and the independent variables: (1) monthly income and (2) level of education. In the analysis, 
the data collected were first analyzed for normality using the logarithmic transformation using Equation (1):

$$
f(x)=\log _{b} x
$$

where $\log _{b} x$ is the base-b logarithm function (base 10 is considered), and $x$ refers to the numerical value of the respondents' answers to each motivator statement, assigned as follows: strongly agree-5; agree -4 ; neutral -3 ; disagree -2 ; and strongly disagree -1 . If data are established as normal, a simple linear regression analysis follows to determine the relationship between the dependent and independent variables following the formula for coefficient of correlation given in Equation (2):

$$
r=\frac{\sum_{i=1}^{n}\left(x_{i}-\bar{x}\right)\left(y_{i}-\bar{y}\right)}{\sqrt{\sum_{i=1}^{n}\left(x_{i}-\bar{x}\right)^{2} \sum_{i=1}^{n}\left(y_{i}-\bar{y}\right)^{2}}}
$$

where $x_{i}$ refers to the respondents' answers for each motivator (dependent variable), $y_{i}$ refers to the corresponding value of the independent variable, $\bar{x}$ refers to the arithmetic mean for all values of $x$, and $\bar{y}$ refers to the arithmetic mean for all values of $y$. If established as non-normal, an ordinal logistic regression analysis is done using SPSS PLUM and the estimated values of $R^{2}$ or the coefficient of determination is used to provide information on how much of the variance in data can be explained by the independent variables, established through Cox and Snell's, Nagelkerke's, and McFadden's pseudo- $R^{2}$ statistics. To represent numerically the independent variables, numerical values are assigned according to Table 2.

Table 2. Equivalent numerical values for educational attainment and income classification.

\begin{tabular}{ccc}
\hline Numerical Value & Income Classification & Educational Attainment \\
\hline 1 & Poor & Elementary level \\
2 & Lower income & Elementary graduate \\
3 & - & High school level \\
4 & - & High school graduate \\
5 & - & College level \\
6 & - & College graduate \\
\hline
\end{tabular}

Note: Income classification is based on monthly income of the household and classified according to [73]. Poor household are those with monthly income below Php 7890, while lower income households are those with monthly income between Php 7891 to Php 15,780.

\section{Results and Discussion}

The 11 household $(\mathrm{HH})$ beneficiaries, composed of 44 individuals, were provided with increased electricity access last March 2020 through a $7.92 \mathrm{kWp}$ solar PV system that was installed on two rooftops within their vicinity. The majority of the beneficiaries were aged below 30 years old (55\%), while $27 \%$ were aged 30 to 59 years, and only $18 \%$ were above 60 years old. Among the beneficiaries, 32\% were only elementary graduates, only $5 \%$ held college degrees, and 9\% were not of school age (see Figure 3 ). The main source of livelihood for the beneficiaries was fishing (11 beneficiaries), while others worked as a restaurant vendor, salesclerk, and hotel housekeeper (four beneficiaries). There were only two beneficiaries who had their own businesses as small vending storeowners, and five of them were working in the local government unit of the island, holding various positions. Other beneficiaries were plain housewives (seven beneficiaries), students/underage (13 beneficiaries), or had no work at all (two beneficiaries). 




Figure 3. Level of education, beneficiaries of the solar PV system in Gilutongan Island, Cebu, Philippines.

Meter readings were obtained every week to determine the electricity consumption per $\mathrm{HH}$ beneficiary. Figure 4 presents the graph of the consumption for all eleven households starting from 30 March 2020 to 13 September 2020. The first week's meter readings were relatively large compared to the succeeding weeks as this was the first reading done since the households were provided with increased electricity access on the first week of March. Three weeks had already lapsed when this reading was made, thus, this first reading was considered to be three weeks of electricity consumption for the households. Disregarding the first week data, the highest recorded meter reading was for HH6 on week 6 at $20.27 \mathrm{kWh}$, while the lowest recorded meter reading was for $\mathrm{HH}$ on week 12 at $0 \mathrm{kWh}$, as this week, no household member was in their house.

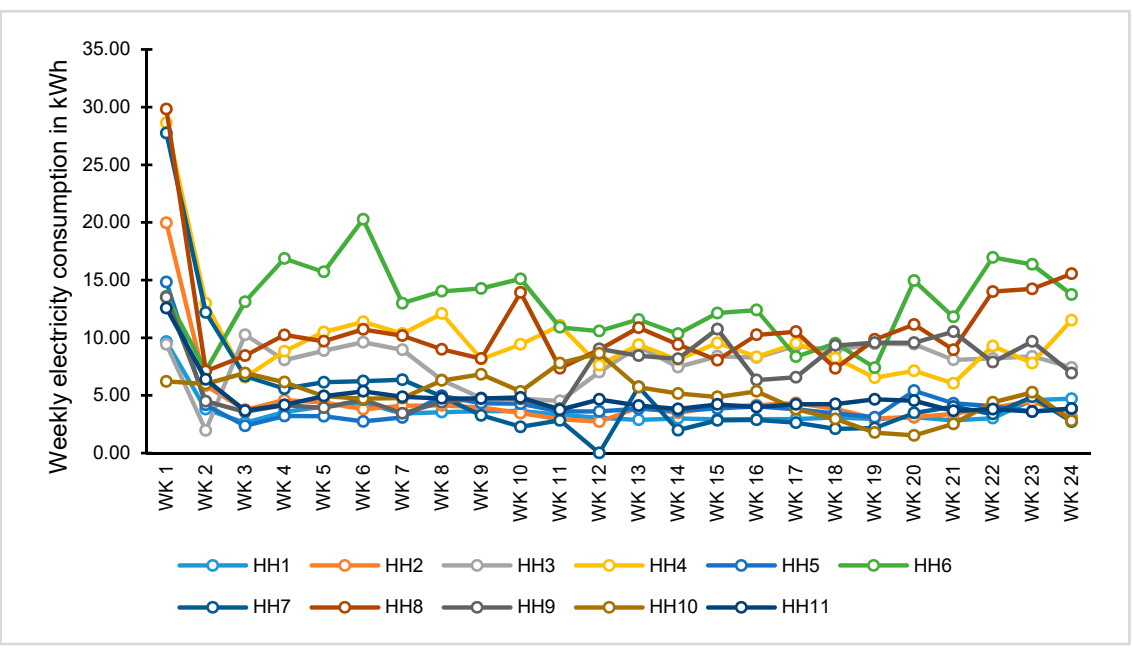

Figure 4. Weekly electricity consumption for 11 households in Gilutongan Island, Cebu, Philippines.

Average actual electricity consumption was computed considering 27 weeks (including the three-week lapsed period when no meter reading was done but electricity consumption had already started). On average, the electricity consumption was $6.14 \mathrm{kWh}$ per week with the highest average recorded by HH6 at $11.49 \mathrm{kWh}$ per week and the lowest average recorded by $\mathrm{HH} 1$ at $3.25 \mathrm{kWh}$ per week (see Figure 5). Based on an initial load profiling survey prior to installation, $\mathrm{HH} 1$ expressed the highest forecasted consumption at $27 \mathrm{kWh}$ per week, while the lowest was HH9 with $0.82 \mathrm{kWh}$ per week. Both households 
recorded the most significant difference in terms of surveyed and actual consumption at $-88 \%$ for $\mathrm{HH} 1$ and $+660 \%$ for $\mathrm{HH} 9$.

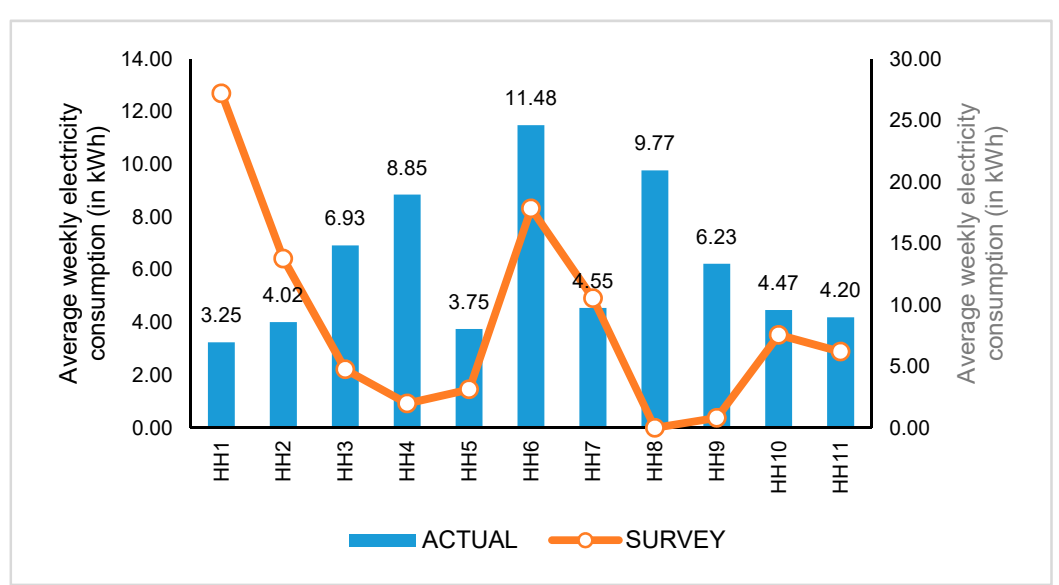

Figure 5. Average weekly electricity consumption, 11 households (Note: HH8 with zero surveyed value was not included in the initial survey).

The majority of the respondents $(72 \%)$ indicated that they were confident in the reliability of the solar photovoltaic system and have acquired or extended their use of household appliances for their convenience and even engaged in small productive uses of electricity to augment their incomes. Moreover, $66 \%$ of the respondents felt that the system could adequately supply their electricity needs. However, some respondents felt that while they were able to increase their duration of electricity use, their inability to use certain appliances as they pleased made them consider the supply to be inadequate or unreliable. Some of the households expressed the desire to use refrigerators since increased access was given but were deterred from doing so because the appliances they wished to use were regarded as inefficient and outdated and the project implementers were cautious to add such appliances to the load of the all-PV system.

Respondents regarded social value as a significant motivator to electricity consumption. The majority of the households $(90 \%)$ agreed that with the 24 -h connection that was provided to them, they experienced increased access to information as they had more time to use televisions or mobile phones that allowed them to communicate and access the internet. The increased duration of electrical appliances, such as electric fans and mobile phones, led $93 \%$ of the respondents to feel strongly driven to consume electricity. However, there were also some households who indicated that their use of rice cookers and electric irons were hampered, thus inferring deterred access to conveniences. In rural isolated islands in the country where electricity was almost never available to the coastal communities for more than $4 \mathrm{~h}$ every day, $93 \%$ of the beneficiaries agreed that having increased access could project better status for the connected households considering that their neighbors only had night-time access. Moreover, this prompted other neighboring households who were not beneficiaries of the project to have other solar developers install solar home systems on their rooftops to also increase their access to electricity. On the other hand, beneficiaries were also motivated to consume by being part of the local association and by having a sense of ownership, as they were told to maintain and operate the system, with $72 \%$ of the respondents indicating agree or strongly agree answers to this factor. However, $3 \%$ of the respondents indicated that being part of the local organization was not a particularly strong motivator for them, further stating that they would prefer to not be part of the organization due to individual differences with the other beneficiaries.

Meanwhile, epistemic value did not strongly influence the beneficiaries to consume electricity. Only $48 \%$ and $28 \%$ of the respondents considered curiosity or prior knowledge of renewable energy technologies, respectively, as motivators to consume electricity for households. Curiosity and prior knowledge were attributed by the respondents to the solar 
installation on the island's local school, as well as solar installations in other neighboring islands. Respondents acknowledged that these installations spurred their interest in the ability of solar PV systems to provide for reliable electricity supply to the consumers. However, several of the respondents felt impartial to these factors as an influence to their current consumption behavior with $48 \%$ for curiosity and $62 \%$ for prior knowledge.

The beneficiaries positively responded to transparency as a motivator to consume electricity, with $83 \%$ of the respondents indicating that the electrical meters allowed them to see their consumption and has encouraged them to use electricity as they can now control their usage. However, $10 \%$ of the respondents said that while it is a good motivator, it does not particularly compel them to use electricity because they also do not know how to do meter readings, thus, it is not specifically helpful to them. On the other hand, $41 \%$ of the respondents said that providing for safety devices, such as switches and circuit breakers, inculcated a sense of security for their households. According to the respondents, witnessing how the generation and distribution systems were installed also attenuated their doubts as to the reliability of the system. However, $31 \%$ of the respondents felt that this was not a strong influence in terms of assuring health and well-being, further stating that they would have preferred the electrification to also provide for better health services to the community above the mere provision of safety electrical devices.

The majority of the respondents agreed that economic value of electrification was a strong motivator for them to consume electricity. In terms of equitability, $79 \%$ of the respondents implied that the current tariff was a reasonable value considering that they now had 24-h electricity access, while $14 \%$ still considered the tariff to be more expensive compared to the mainland. Of the respondents, there were $76 \%$ who engaged in productive uses of electricity (PUEs), prompting them to use electricity for longer periods during the day. One of the households acquired a freezer and sold ice and other ice treats on the island. Other households, who already owned small stores prior to the solar PV installation, extended operating hours of their videoke machines. Still other households engaged in other simple PUEs, such as mobile charging and cold-water machines. Although the households collectively indicated that they would have wanted to further use additional electrical appliances to improve their income-generating activities but were discouraged to do so, they still found that the system was able to provide them with enough capacity to engage in productive uses of electricity, albeit modestly.

\subsection{What Motivates Rural Households to Consume Electricity?}

In determining the degree to which households were motivated to consume electricity, modes were calculated for each of the factors summarized in Table 3. All identified factors ranged between moderate motivators to strong motivators for the households to consume electricity, except for the $\mathrm{M}_{7}$ (satisfying curiosity or RET), $\mathrm{M}_{8}$ (satisfying prior knowledge of RET), and $\mathrm{M}_{10}$ (assurance in health and well-being), which respondents indicated were neutral in terms of motivating them to consume electricity. Of note were the strong motivators - better status in local community $\left(\mathrm{M}_{5}\right)$ and ability to engage in PUE $\left(\mathrm{M}_{12}\right)$. The increased electricity access was seen by the beneficiaries as progress for their social standing in the community and, per discussions and observations, have prompted neighboring households to commission other solar PV developers to install solar home systems in their houses. Moreover, as the households were required to pay for electricity consumption, most of them were encouraged to engage in productive uses of electricity to improve their income-generation activities. While some households were deterred from using their old electrical appliances, particularly refrigerators, some households invested in acquiring new and energy-efficient freezers to start an ice-making business. Likewise, households engaged in moderate productive activities using electricity, with five households engaged in mobile charging for a fee and one household selling cold water using water-cooling machines. Means still suggest that both $\mathrm{M}_{5}$ and $\mathrm{M}_{12}$ are among the strong motivators to electricity consumption, along with increased access to information $\left(\mathrm{M}_{3}\right)$ and conveniences $\left(\mathrm{M}_{4}\right)$, as well as transparency of the system $\left(\mathrm{M}_{9}\right)$. 
Table 3. Descriptive statistics for motivators.

\begin{tabular}{cccccc}
\hline Motivator & Mean & Median & Mode & Skewness & Kurtosis \\
\hline $\mathrm{M}_{1}$ : Confidence in system reliability & 3.76 & 4.00 & 4.00 & -0.901 & 0.210 \\
$\mathrm{M}_{2}$ : Confidence in adequacy of supply & 3.62 & 4.00 & 4.00 & -0.593 & -0.713 \\
$\mathrm{M}_{3}$ : Increased access to information & 4.38 & 4.00 & 5.00 & -0.641 & -0.570 \\
$\mathrm{M}_{4}$ : Increased access to conveniences & 4.34 & 4.00 & 4.00 & -0.349 & -0.566 \\
$\mathrm{M}_{5}$ : Better status in the local community & 4.52 & 5.00 & 5.00 & -0.974 & 0.010 \\
$\mathrm{M}_{6}$ : Local organization/ownership & 3.97 & 4.00 & 4.00 & -1.201 & 1.868 \\
$\mathrm{M}_{7}$ : Satisfying curiosity of RE & 3.55 & 3.00 & 3.00 & -0.345 & 1.425 \\
$\mathrm{M}_{8}$ : Satisfying prior knowledge of RE & 3.14 & 3.00 & 3.00 & -0.558 & 1.474 \\
$\mathrm{M}_{9}$ : Transparency of the system & 4.21 & 4.00 & 5.00 & -1.067 & 0.600 \\
$\mathrm{M}_{10}$ : Assurance in health/well-being & 3.14 & 3.00 & 3.00 & -0.154 & -0.821 \\
$\mathrm{M}_{11}$ : Equitability of tariff & 3.90 & 4.00 & 4.00 & -1.319 & 1.323 \\
$\mathrm{M}_{12}$ : Ability to engage in PUE & 4.17 & 5.00 & 5.00 & -1.049 & -0.305 \\
\hline
\end{tabular}

It can be observed that all motivators have negative skewness, signifying non-symmetry, although results for $\mathrm{M}_{4}, \mathrm{M}_{7}$, and $\mathrm{M}_{10}$ can be considered fairly symmetrical. Local ownership $\left(\mathrm{M}_{6}\right)$ and equitability of tariff $\left(\mathrm{M}_{11}\right)$ results are highly skewed to the negative side, suggesting that a higher proportion of the minority of the respondents considered these factors as low motivators to consume electricity. However, all other values for skewness suggest acceptable levels. Meanwhile, it can also be observed that $\mathrm{M}_{6}, \mathrm{M}_{7}, \mathrm{M}_{8}$, and $\mathrm{M}_{11}$ are heavy-tailed to the right side, although values for kurtosis are also within acceptable levels.

\subsection{Household Income and Educational Attainment as Influencers to Motivate Electricity Consumption}

Figure 6 shows the histogram for each motivator. The test for normality indicates that logarithmically-transformed data for the motivators under the functional, social, epistemic, and economic values are not normally distributed with $p$-values of less than 0.05 , while data for the motivators under the emotional value are normally distributed with $p$-values of greater than 0.05 (see Table 4). As such, analysis for correlation of the motivators under the functional, social, epistemic, and economic values is done using ordinal regression, while the analysis for correlation of the motivators under the emotional value is done using simple regression.

Table 4. $p$-values for logarithmically-transformed data for the motivators.

\begin{tabular}{ccc}
\hline Motivator & Kolmogorov-Smirnov Test & Shapiro-Wilk Test \\
\hline Log-transformed functional value & 0.001 & 0.003 \\
Log-transformed social value & 0.008 & 0.002 \\
Log-transformed epistemic value & 0.001 & 0.001 \\
Log-transformed emotional value & 0.060 & 0.061 \\
Log-transformed economic value & 0.001 & 0.001 \\
\hline
\end{tabular}

Table 5 summarizes the results of the regression analysis. With values for coefficients of correlation and determination falling below the 0.7 to 1.0 range, results suggest that the degree to which motivators drive the respondents to consume electricity is not influenced by either their income or their educational attainment. Both independent variables are weakly correlated to the motivators, suggesting that the income and educational attainment of the respondents do not predict how they are driven to consume electricity. This suggests that household monthly income and respondent educational attainment are insignificant predictors to the motivators of electricity consumption for the community beneficiaries. 

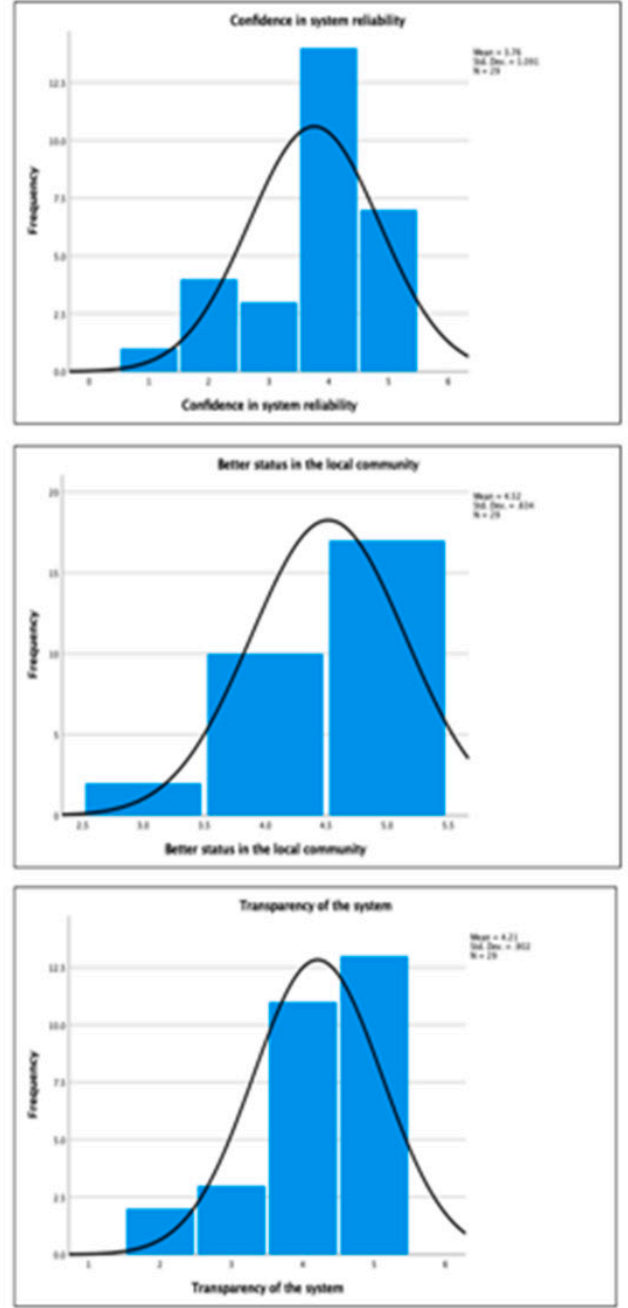

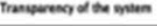
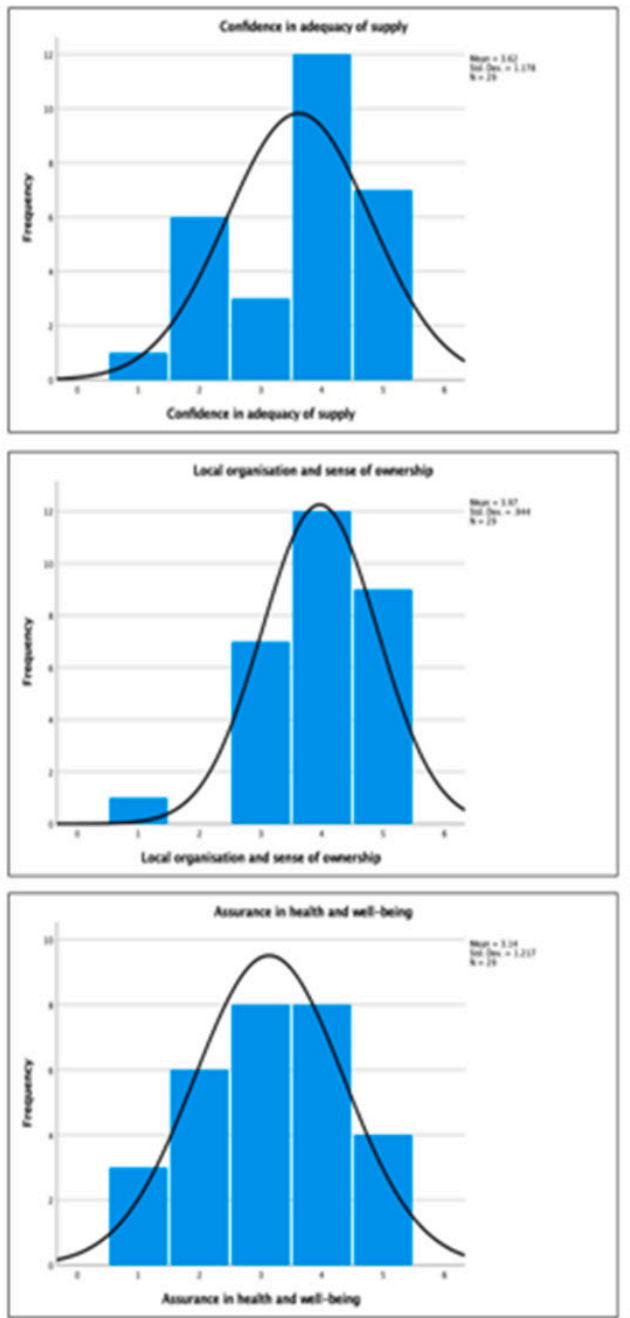
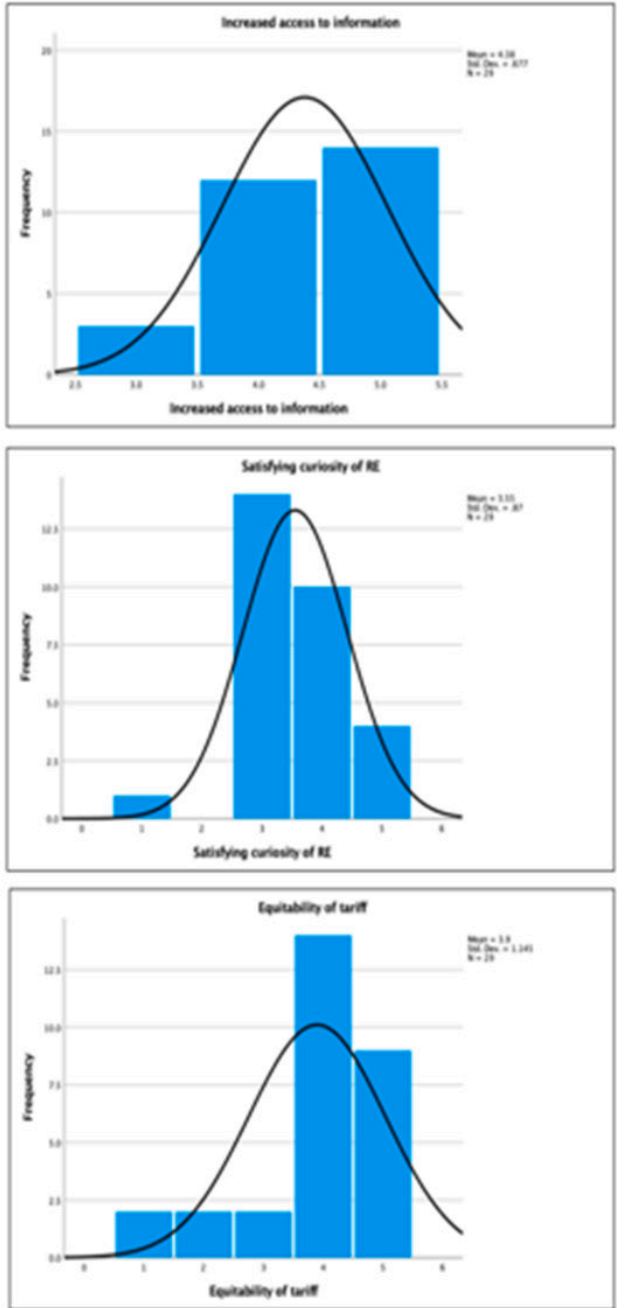

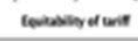
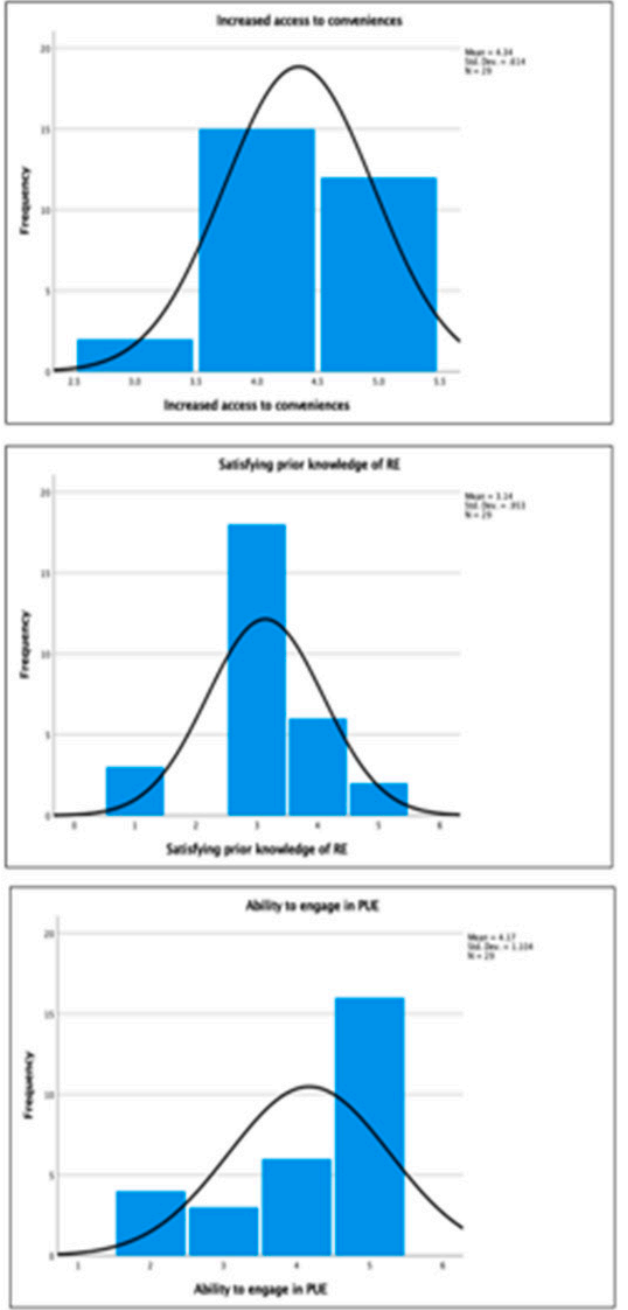

Figure 6. Histogram per motivator 
Table 5. Regression analysis, motivators v. income and educational attainment.

\begin{tabular}{|c|c|c|c|c|c|c|}
\hline \multirow{2}{*}{ Motivator } & \multicolumn{6}{|c|}{ Coefficient of Correlation } \\
\hline & \multicolumn{3}{|c|}{ Household Monthly Income } & \multicolumn{3}{|c|}{ Respondent Educational Attainment } \\
\hline $\mathrm{M}_{9}:$ Transparency of the system & \multicolumn{3}{|c|}{0.095} & \multicolumn{3}{|c|}{-0.272} \\
\hline $\mathrm{M}_{10}:$ Assurance in health/well-being & \multicolumn{3}{|c|}{0.133} & \multicolumn{3}{|c|}{-0.055} \\
\hline \multirow{3}{*}{ Motivator } & \multicolumn{6}{|c|}{ Estimated Coefficient of Determination } \\
\hline & \multicolumn{3}{|c|}{ Household Monthly Income } & \multicolumn{3}{|c|}{ Respondent Educational Attainment } \\
\hline & $\begin{array}{c}\text { Cox and } \\
\text { Snell }\end{array}$ & Nagelkerke & McFadden & $\begin{array}{c}\text { Cox and } \\
\text { Snell }\end{array}$ & Nagelkerke & McFadden \\
\hline $\mathrm{M}_{1}$ : Confidence in system reliability & 0.024 & 0.026 & 0.009 & 0.104 & 0.112 & 0.041 \\
\hline $\mathrm{M}_{2}$ : Confidence in adequacy of supply & 0.020 & 0.022 & 0.007 & 0.210 & 0.224 & 0.085 \\
\hline $\mathrm{M}_{3}$ : Increased access to information & 0.031 & 0.037 & 0.017 & 0.223 & 0.262 & 0.133 \\
\hline $\mathrm{M}_{4}$ : Increased access to conveniences & 0.074 & 0.089 & 0.043 & 0.296 & 0.356 & 0.197 \\
\hline $\mathrm{M}_{5}$ : Better status in the local community & 0.051 & 0.063 & 0.031 & 0.186 & 0.226 & 0.119 \\
\hline $\mathrm{M}_{6}:$ Local organization/ownership & 0.051 & 0.057 & 0.022 & 0.174 & 0.192 & 0.081 \\
\hline $\mathrm{M}_{7}$ : Satisfying curiosity of RE & 0.009 & 0.010 & 0.004 & 0.170 & 0.190 & 0.081 \\
\hline $\mathrm{M}_{8}$ : Satisfying prior knowledge of RE & 0.004 & 0.004 & 0.001 & 0.220 & 0.230 & 0.080 \\
\hline $\mathrm{M}_{11}:$ Equitability of tariff & 0.022 & 0.023 & 0.009 & 0.201 & 0.218 & 0.088 \\
\hline $\mathrm{M}_{12}:$ Ability to engage in PUE & 0.024 & 0.027 & 0.010 & 0.208 & 0.231 & 0.100 \\
\hline
\end{tabular}

\section{Potential Impacts to Rural Island Electrification in the Philippines}

As the Philippines is steadily working towards the provision of electricity to rural communities and far-flung areas, the focus has strongly been on the technological and economic aspects of the projects with little emphasis on what motivates end-users to consume electricity. While looking at these two dimensions could profoundly impact project deployments, proactive consumption by the end-users should also be emphasized. Sustainability is primarily supported by the proactive use of electricity by the consumers and only secondarily by the design, the techno-economic studies, and the multidimensional sustainability assessments. Without proactive consumption, any sound project deployment is eventually bound to fail. The proposed multidimensional assessment framework for electricity consumption drivers, strongly based on the user-perceived value of electricity service, could be a beneficial tool for policymakers in the country to determine what particularly motivates rural households to consume electricity. Policies could then be designed around these motivators to ensure that households are encouraged to utilize electricity. Such as the case presented in this research, strong motivators to consume electricity hinge on the promotion of better status in the community and the ability to engage in productive uses of electricity. In providing increased electricity access to communities such as this, it would be logical to also consider how electricity can impact the social lives of the inhabitants, as well as provide policies to support beneficiaries to engage in productive uses of electricity.

\section{Conclusions}

The assessment of the sustainability of rural electrification typically focuses on technological, economic, environment, social, and institutional factors. However, the proactive consumption of electricity by the end-consumers is a more pragmatic but often overlooked factor to sustainability. There is very limited literature that looks into what drives rural consumers to utilize electricity, but the proactive consumption of electricity by the end-users is deemed crucial to the successful implementation of decentralized electrification systems, particularly renewable energy technologies, especially in rural areas where day-to-day living and income generation activities are not reliant on electricity access. This study proposes a multidimensional assessment framework composed of 12 motivators, primarily based on user perceived value of electricity service, to determine what motivates house- 
holds to consume electricity. The framework was applied in a sub-village in Gilutongan Island, Cordova, Cebu, Philippines, where a $7.92 \mathrm{kWp}$ solar photovoltaic system was installed 2 March 2020. The results of the study indicate that the households largely considered 9 of the 12 motivators to have moderate to strong influence on their consumption patterns. However, the epistemic value and the assurance to health and well-being were neutral values in terms of motivating the beneficiaries to consume electricity. Moreover, better status for the households in the community and the ability to engage in productive uses of electricity are considered to be the strongest motivators for the beneficiaries to consume electricity. The motivation to consume electricity is neither influenced by the household's monthly income nor the educational attainment of the respondents. It is important to note that this study derives results from a survey of only 29 respondents from 11 households who benefited from the solar PV installation, thus, the limitation to the generalizability of the findings. Further studies could be done to validate with an increased sample size.

However, this simple and pragmatic assessment framework could provide policymakers a logical approach to understand what drives rural households to consume electricity. The information derived from this assessment could help shape strong strategies to develop rural electrification and could promote better policymaking to support project sustainability. Determining and understanding what motivates users to consume electricity could help decision makers, as well as project developers, to plan for support or supplementary services that could promote proactive consumption by the end-users. This, in turn, enhances the sustainability of decentralized electrification systems implemented in rural, isolated areas.

Author Contributions: L.L., conceptualization, methodology, validation, formal analysis, investigation, writing — original draft preparation, writing—-review and editing; E.T., conceptualization, writing - review and editing, supervision, funding acquisition. Both authors have read and agreed to the published version of the manuscript.

Funding: This research is funded by the European Union Access to Sustainable Energy Programme (EUASEP) through the Clean Energy Living Laboratories (CELLs) project with Contract No. 2017/392-650.

Institutional Review Board Statement: The study was conducted with the approval of the University of San Carlos Research Ethics Committee (Protocol Number 010/2018-03-lozano and Date of Approval 7 May 2018).

Informed Consent Statement: Informed consent was obtained from all subjects involved in the study.

Data Availability Statement: Data is available upon request.

Acknowledgments: The authors would like to extend their gratitude to Engineering Research and Development for Technology (ERDT) under the Philippine Department of Science and Technology (DOST) for providing the scholarship grant for L. Lozano; to the EU-ASEP funded project on Clean Energy Living Laboratories of the University of San Carlos Center for Research in Energy Systems and Technologies (USC-CREST, www.crest.org.ph, and the Ateneo de Manila University School of Government (ASOG, www.ateneo.edu/aps/asog) for granting the opportunity to do this work and the financial support. Acknowledgement is also due to the community and local government unit of Gilutongan Island for facilitating our field work; and to Edward Querikiol, Arben Vallente, and Teepu Cedi Camba for their invaluable support in the data collection for this research.

Conflicts of Interest: The authors declare no conflict of interest. 


\section{Appendix A}

Table A1. Statements Regarding Motivators to Consume Electricity in Rural Households.

\begin{tabular}{|c|c|c|c|}
\hline & Motivator & Consumer Value & Statements Degree of Motivation to Consume \\
\hline $\mathrm{M}_{1}$ & Confidence in system reliability & Functional value & $\begin{array}{l}\text { I am motivated to consume electricity because I am confident } \\
\text { that the solar PV system is reliable and will not break down } \\
\text { despite using various electrical appliances. }\end{array}$ \\
\hline $\mathrm{M}_{2}$ & Confidence in adequacy of supply & Functional value & $\begin{array}{l}\text { I am motivated to consume electricity because I am confident } \\
\text { that the system supply is enough to provide for the } \\
\text { requirements in powering up the electrical appliances that I } \\
\text { wish to use. }\end{array}$ \\
\hline $\mathrm{M}_{3}$ & Increased access to information & Social value & $\begin{array}{l}\text { I am motivated to consume electricity because it has provided } \\
\text { my household increased access to information and knowledge } \\
\text { attainment through television, internet, and other media. }\end{array}$ \\
\hline $\mathrm{M}_{4}$ & Increased access to conveniences & Social value & $\begin{array}{l}\text { I am motivated to consume electricity because it has provided } \\
\text { my household with increased access to conveniences such as } \\
\text { electric fans and rice cookers. }\end{array}$ \\
\hline $\mathrm{M}_{5}$ & $\begin{array}{l}\text { Better status in the } \\
\text { local community }\end{array}$ & Social value & $\begin{array}{l}\text { I am motivated to consume electricity because having increased } \\
\text { access has conveyed better status for my household in relation } \\
\text { to our neighbours. }\end{array}$ \\
\hline $\mathrm{M}_{6}$ & $\begin{array}{l}\text { Local organization and } \\
\text { sense of ownership }\end{array}$ & Social value & $\begin{array}{l}\text { I am motivated to consume electricity because my household is } \\
\text { part of an organization that manages the solar PV system, and it } \\
\text { has provided me with a sense of ownership of the system. }\end{array}$ \\
\hline $\mathrm{M}_{7}$ & $\begin{array}{l}\text { Satisfying curiosity of } \\
\text { renewable energy }\end{array}$ & Epistemic value & $\begin{array}{l}\text { I am motivated to consume electricity because I want to satisfy } \\
\text { my curiosity with regards to renewable energy technologies as } \\
\text { electricity sources. }\end{array}$ \\
\hline $\mathrm{M}_{8}$ & $\begin{array}{l}\text { Satisfying prior knowledge of } \\
\text { renewable energy }\end{array}$ & Epistemic value & $\begin{array}{l}\text { I am motivated to consume electricity because I want to satisfy } \\
\text { my prior knowledge of renewable energy technologies. }\end{array}$ \\
\hline $\mathrm{M}_{9}$ & Transparency of the system & Emotional value & $\begin{array}{l}\text { I am motivated to consume electricity because I am able to } \\
\text { determine and control our consumption through electrical } \\
\text { meters installed in my household. }\end{array}$ \\
\hline $\mathrm{M}_{10}$ & $\begin{array}{l}\text { Assurance in health and } \\
\text { well-being }\end{array}$ & Emotional value & $\begin{array}{l}\text { I am motivated to consume electricity because this has assured } \\
\text { the health and safety of my household members. }\end{array}$ \\
\hline $\mathrm{M}_{11}$ & Equitability of tariff & Economic value & $\begin{array}{l}\text { I am motivated to consume electricity because the tariff is more } \\
\text { equitable now that we have increased access as } \\
\text { compared to before. }\end{array}$ \\
\hline $\mathrm{M}_{12}$ & $\begin{array}{l}\text { Ability to engage in productive } \\
\text { uses of electricity (PUE) }\end{array}$ & Economic value & $\begin{array}{l}\text { I am motivated to consume electricity because this has allowed } \\
\text { my household to use appliances and tools that can improve our } \\
\text { income-generating activities. }\end{array}$ \\
\hline
\end{tabular}

\section{References}

1. The World Bank. Tracking SDG7: The Energy Progress Report 2019; Access to electricity; The World Bank: Washington, DC, USA, 2019; pp. 1-26.

2. United Nations Department of Economic and Social Affairs. SDG 7-Progress and Info 2020; United Nations: New York, NY, USA, 2020.

3. International Energy Agency. Energy Access Outlook; International Energy Agency: Paris, France, 2017.

4. Sapkota, A.; Lu, Z.; Yang, H.; Wang, J. Role of renewable energy technologies in rural communities' adaptation to climate change in Nepal. Renew. Energy 2014, 68, 793-800. [CrossRef]

5. Rahman, M.M.; Paatero, J.V.; Lahdelma, R. Evaluation of choices for sustainable rural electrification in developing countries: A multicriteria approach. Energy Policy 2013, 59, 589-599. [CrossRef]

6. Müller, M.F.; Thompson, S.E.; Kelly, M.N. Bridging the information gap: A webGIS tool for rural electrification in data-scarce regions. Appl. Energy 2016, 171, 277-286. [CrossRef]

7. Odou, O.D.T.; Bhandari, R.; Adamou, R. Hybrid off-grid renewable power system for sustainable rural electrification in Benin. Renew. Energy 2020, 145, 1266-1279. [CrossRef] 
8. Boulmrharj, S.; NaitMalek, Y.; Elmouatamid, A.; Bakhouya, M.; Ouladsine, R.; Zine-Dine, K.; Khaidar, M.; Abid, R. Approach for dimensioning stand-alone photovoltaic systems. Energy Procedia 2018, 153, 56-61. [CrossRef]

9. Gaur, A.S.; Das, P.; Jain, A.; Bhakar, R.; Mathur, J. Long-term energy system planning considering short-term operational constraints. Energy Strateg. Rev. 2019, 26, 100383. [CrossRef]

10. Mainali, B.; Silveira, S. Alternative pathways for providing access to electricity in developing countries. Renew. Energy 2013, 57, 299-310. [CrossRef]

11. Müller, M.F.; Thompson, S.E.; Gadgil, A.J. Estimating the price (in)elasticity of off-grid electricity demand. Dev. Eng. 2017, 3, 12-22. [CrossRef]

12. Blodgett, C.; Dauenhauer, P.; Louie, H.; Kickham, L. Accuracy of energy-use surveys in predicting rural mini-grid user consumption. Energy Sustain. Dev. 2017, 41, 88-105. [CrossRef]

13. Mahapatra, S.; Dasappa, S. Rural electrification: Optimising the choice between decentralised renewable energy sources and grid extension. Energy Sustain. Dev. 2012, 16, 146-154. [CrossRef]

14. Sato, T.; Ide, J.; Isa, M.A.; Rahadian, F.; Tokihiko, F.; Yukihiro, S. A Challenge for Sustainable Electrification, Respecting the Local Tradition in Ciptagelar Village, West Java, Indonesia: Complementary Approach with a Private Company. Energy Procedia 2017, 141, 4-8. [CrossRef]

15. Leary, J.; Schaube, P.; Clementi, L. Rural electrification with household wind systems in remote high wind regions. Energy Sustain. Dev. 2019, 52, 154-175. [CrossRef]

16. Eras-Almeida, A.A.; Fernández, M.; Eisman, J.; Martín, J.G.; Caamaño, E.; Egido-Aguilera, M.A. Lessons learned from rural electrification experiences with third generation solar home systems in latin America: Case studies in Peru, Mexico, and Bolivia. Sustainability 2019, 11, 7139. [CrossRef]

17. Barnes, D.F. Effective solutions for rural electrification in developing countries: Lessons from successful programs. Curr. Opin. Environ. Sustain. 2011, 3, 260-264. [CrossRef]

18. Palit, D.; Bandyopadhyay, K.R. Rural electricity access in South Asia: Is grid extension the remedy? A critical review. Renew. Sustain. Energy Rev. 2016, 60, 1505-1515. [CrossRef]

19. Pigaht, M.; van der Plas, R.J. Innovative private micro-hydro power development in Rwanda. Energy Policy 2009, 37, 4753-4760. [CrossRef]

20. Diemuodeke, E.O.; Briggs, T.A. Policy pathways for renewable and sustainable energy utilisation in rural coastline communities in the Niger Delta zone of Nigeria. Energy Rep. 2018, 4, 638-644. [CrossRef]

21. Rolland, S. Switched on to mini grids. Renew. Energy Focus 2011, 12, 10-12. [CrossRef]

22. Chaurey, A.; Ranganathan, M.; Mohanty, P. Electricity access for geographically disadvantaged rural communities-technology and policy insights. Energy Policy 2004, 32, 1693-1705. [CrossRef]

23. Adusah-Poku, F.; Takeuchi, K. Determinants and welfare impacts of rural electrification in Ghana. Energy Sustain. Dev. 2019, 52, 52-62. [CrossRef]

24. Costello, K.W. Electrification: The nexus between consumer behavior and public policy. Electr. J. 2018, 31, 1-7. [CrossRef]

25. Ilskog, E. Indicators for assessment of rural electrification-An approach for the comparison of apples and pears. Energy Policy 2008, 36, 2665-2673. [CrossRef]

26. Ilskog, E.; Kjellstrom, B. And then they lived sustainably ever after?-Assessment of rural electrification cases by means of indicators. Energy Policy 2008, 36, 2674-2684. [CrossRef]

27. López-González, A.; Ferrer-Martí, L.; Domenech, B. Sustainable rural electrification planning in developing countries: A proposal for electrification of isolated communities of Venezuela. Energy Policy 2019, 129, 327-338. [CrossRef]

28. Mainali, B.; Pachauri, S.; Rao, N.D.; Silveira, S. Assessing rural energy sustainability in developing countries. Energy Sustain. Dev. 2014, 19, 15-28. [CrossRef]

29. Mainali, B.; Silveira, S. Using a sustainability index to assess energy technologies for rural electrification. Renew. Sustain. Energy Rev. 2015, 41, 1351-1365. [CrossRef]

30. Hirmer, S.; Guthrie, P. Identifying the needs of communities in rural Uganda: A method for determining the 'User-Perceived Value' of rural electrification initiatives. Renew. Sustain. Energy Rev. 2016, 66, 476-486. [CrossRef]

31. Tesfamichael, M.; Bastille, C.; Leach, M. Eager to connect, cautious to consume: An integrated view of the drivers and motivations for electricity consumption among rural households in Kenya. Energy Res. Soc. Sci. 2020, 63, 101394. [CrossRef]

32. González, A.M.; Sandoval, H.; Acosta, P.; Henao, F. On the acceptance and sustainability of renewable energy projects-a systems thinking perspective. Sustainability 2016, 8, 1171. [CrossRef]

33. Hirmer, S.; Cruickshank, H. The user-value of rural electrification: An analysis and adoption of existing models and theories. Renew. Sustain. Energy Rev. 2014, 34, 145-154. [CrossRef]

34. Rogers, E.M. Diffusion of Innovations, 4th ed.; Simon and Schuster: New York, NY, USA, 2010.

35. Graber, S.; Narayanan, T.; Alfaro, J.; Palit, D. Solar microgrids in rural India: Consumers' willingness to pay for attributes of electricity. Energy Sustain. Dev. 2018, 42, 32-43. [CrossRef]

36. Müggenburg, H.; Tillmans, A.; Schweizer-Ries, P.; Raabe, T.; Adelmann, P. Social acceptance of PicoPV systems as a means of rural electrification-A socio-technical case study in Ethiopia. Energy Sustain. Dev. 2012, 16, 90-97. [CrossRef]

37. Shakya, B.; Bruce, A.; MacGill, I. Survey based characterisation of energy services for improved design and operation of standalone microgrids. Renew. Sustain. Energy Rev. 2019, 101, 493-503. [CrossRef] 
38. Lopez-Gonazels, A.; Ranaboldo, M.; Domenech, B.; Ferrer-Marti, L. Evaluation of small wind turbines for rural electrification: Case studies from extreme climatic conditions in Venezuela. Energy 2020, 209, 118450. [CrossRef]

39. Yadav, P.; Davies, P.J.; Palit, D. Distributed solar photovoltaics landscape in Uttar Pradesh, India: Lessons for transition to decentralised rural electrification. Energy Strateg. Rev. 2019, 26, 100392. [CrossRef]

40. Aklin, M.; Cheng, C.Y.; Urpelainen, J. Social acceptance of new energy technology in developing countries: A framing experiment in rural India. Energy Policy 2018, 113, 466-477. [CrossRef]

41. Opiyo, N.N. Impacts of neighbourhood influence on social acceptance of small solar home systems in rural western Kenya. Energy Res. Soc. Sci. 2019, 52, 91-98. [CrossRef]

42. Heras-Saizarbitoria, I.; Zamanillo, I.; Laskurain, I. Social acceptance of ocean wave energy: A case study of an OWC shoreline plant. Renew. Sustain. Energy Rev. 2013, 27, 515-524. [CrossRef]

43. Shyu, C.W. End-users' experiences with electricity supply from stand-alone mini-grid solar PV power stations in rural areas of western China. Energy Sustain. Dev. 2013, 17, 391-400. [CrossRef]

44. Soltani, M.; Rahmani, O.; Pour, A.B.; Ghaderpour, Y.; Ngah, I.; Misnan, S.H. Determinants of variation in household energy choice and consumption: Case from Mahabad City, Iran. Sustainability 2019, 11, 4775. [CrossRef]

45. Räty, R.; Carlsson-kanyama, A. Comparing Energy Use by Gender, Age and Income in some European Countries; FOI, Swedish Defence Research Agency: Stockholm, Sweden, 2009.

46. Shen, M.; Sun, H.; Lu, Y. Household electricity consumption prediction under multiple behavioural intervention strategies using support vector regression. Energy Procedia 2017, 142, 2734-2739. [CrossRef]

47. Kostakis, I. Socio-demographic determinants of household electricity consumption: Evidence from Greece using quantile regression analysis. Curr. Res. Environ. Sustain. 2020, 1, 23-30. [CrossRef]

48. Sharma, A.; Agrawal, S.; Urpelainen, J. The adoption and use of solar mini-grids in grid-electrified Indian villages. Energy Sustain. Dev. 2020, 55, 139-150. [CrossRef]

49. Cuesta, M.A.; Castillo-Calzadilla, T.; Borges, C.E. A critical analysis on hybrid renewable energy modeling tools: An emerging opportunity to include social indicators to optimise systems in small communities. Renew. Sustain. Energy Rev. 2020, $122,109691$. [CrossRef]

50. Fuentes, M.; Vivar, M.; Hosein, H.; Aguilera, J.; Muñoz-Cerón, E. Lessons learned from the field analysis of PV installations in the Saharawi refugee camps after 10 years of operation. Renew. Sustain. Energy Rev. 2018, 93, 100-109. [CrossRef]

51. Kirchhoff, H.; Strunz, K. Key drivers for successful development of peer-to-peer microgrids for swarm electrification. Appl. Energy 2019, 244, 46-62. [CrossRef]

52. Hirmer, S.; Guthrie, P. The benefits of energy appliances in the off-grid energy sector based on seven off-grid initiatives in rural Uganda. Renew. Sustain. Energy Rev. 2017, 79, 924-934. [CrossRef]

53. Bisaga, I.; Parikh, P. To climb or not to climb? Investigating energy use behaviour among Solar Home System adopters through energy ladder and social practice lens. Energy Res. Soc. Sci. 2018, 44, 293-303. [CrossRef]

54. Chaurey, A.; Kandpal, T.C. Assessment and evaluation of PV based decentralized rural electrification: An overview. Renew. Sustain. Energy Rev. 2010, 14, 2266-2278. [CrossRef]

55. Ahlborg, H.; Hammar, L. Drivers and barriers to rural electrification in tanzania and mozambique-Grid-extension, off-grid, and renewable energy technologies. Renew. Energy 2014, 61, 117-124. [CrossRef]

56. Wang, J. Information Systems and New Applications in the Service Sector: Models and Methods; IGI Global: Hershey, PA, USA, 2010.

57. Waheed, N.; Hassan, Z. Influence of Customer Perceived Value on Tourist Satisfaction and Revisit Intention: A study on Guesthouses in Maldives. Int. J. Account. Bus. Manag. 2016, 4, 98-119. [CrossRef]

58. Moosa, M.Y.; Hassan, Z. Customer Perceived Values Associated with Automobile and Brand Loyalty. Int. J. Account. Bus. Manag. 2015, 4, 92-107. [CrossRef]

59. Carlson, J.; O'Cass, A.; Ahrholdt, D. Assessing customers' perceived value of the online channel of multichannel retailers: A two country examination. J. Retail. Consum. Serv. 2015, 27, 90-102. [CrossRef]

60. Pihlström, M. Perceived Value of Mobile Service Use and Its Consequences; Swedish School of Economics and Business Administration: Stockholm, Sweden, 2008

61. Mesquita, A. User Perception and Influencing Factors of Technology in Everyday Life; IGI Global: Hershey, PA, USA, 2012.

62. Yu, J.; Lee, H.; Ha, I.; Zo, H. User acceptance of media tablets: An empirical examination of perceived value. Telemat. Inform. 2017, 34, 206-223. [CrossRef]

63. Kuo, Y.F.; Wu, C.M.; Deng, W.J. The relationships among service quality, perceived value, customer satisfaction, and post-purchase intention in mobile value-added services. Comput. Human Behav. 2009, 25, 887-896. [CrossRef]

64. Hong, G.W.; Abe, N. Sustainability assessment of renewable energy projects for off-grid rural electrification: The Pangan-an Island case in the Philippines. Renew. Sustain. Energy Rev. 2012, 16, 54-64. [CrossRef]

65. Almeshqab, F.; Ustun, T.S. Lessons learned from rural electrification initiatives in developing countries: Insights for technical, social, financial and public policy aspects. Renew. Sustain. Energy Rev. 2019, 102, 35-53. [CrossRef]

66. NRECA International. Financial Analysis of Rural Electrifi cation Projects; NRECA International: Arlington, VA, USA, 2010.

67. Glemarec, Y. Financing off-grid sustainable energy access for the poor. Energy Policy 2012, 47, 87-93. [CrossRef]

68. Fedrizzi, M.C.; Ribeiro, F.S.; Zilles, R. Lessons from field experiences with photovoltaic pumping systems in traditional communities. Energy Sustain. Dev. 2009, 13, 64-70. [CrossRef] 
69. Penteado, I.M.; do Nascimento, A.C.S.; Corrêa, D.; Moura, E.A.F.; Zilles, R.; Gomes, M.C.R.L.; Pires, F.J.; Brito, O.S.; da Silva, J.F.; Reis, A.V.; et al. Among people and artifacts: Actor-Network Theory and the adoption of solar ice machines in the Brazilian Amazon. Energy Res. Soc. Sci. 2019, 53, 1-9. [CrossRef]

70. Eder, J.M.; Mutsaerts, C.F.; Sriwannawit, P. Mini-grids and renewable energy in rural Africa: How diffusion theory explains adoption of electricity in Uganda. Energy Res. Soc. Sci. 2015, 5, 45-54. [CrossRef]

71. Sriwannawit, P.; Laestadius, S. Diffusion of photovoltaic systems for rural electrification in Thailand. Int. J. Energy Environ. 2013, 4, 49-58.

72. Joshi, A.; Kale, S.; Chandel, S.; Pal, D. Likert Scale: Explored and Explained. Br. J. Appl. Sci. Technol. 2015, 7, 396-403. [CrossRef]

73. Albert, J.; Santos, A.; Vizmanos, J. Profile and Determinants of the Middle-Income Class in the Philippines; Philippine Institute for Development Studies: Quezon City, Philippine, 2019. 